UDK 821.111-3

\title{
O. Kozii
}

\section{THE IMAGE OF A TREE AS THE EMBODIMENT OF PHILOSOPHICAL CONCEPTS IN J. R. R. TOLKIEN'S OEUVRE}

English linguist J. R. R. Tolkien is world-famous as the creator of the fantasy genre and the author of the epic novel «The Lord of the Rings» which has overgrown the measures of a novel having become a cultural phenomena. The researcher V. Zavadskaya emphasizes Tolkien's role as «the demiurge, the ruler of cosmogonic power, the creator of the universe» [7, p. 52]. Professor once confessed to his biographer and close friend H. Carpenter that, creating «The Silmarillion», he believed that he was not just inventing the plot. Those stories, he said, «arose in his consciousness as something certain. $<\ldots>$ All the time, he felt that he wrote something "existing" and not fictitious» [1, p. 147]. And as a result an extremely real world was created. It cannot be called artistic, as its reality extends beyond the limits of a particular work. The achievement of Tolkien is creating his personal mythology; he was a man who, according to his contemporary, K. Lewis, "visited the inner world of the language» [1, p. 208], for several decades of life he was creating an epochal thing of mythology. It was «The Silmarillion», and not the «Lord of the Rings» which the writer himself considered the work of own life. The Middle Earth is perceived by the reader as a real world as it is created by divine entities, experiencing the times of its birth and destruction. The look at Arda by the eyes of the demiurge is new, but not unusual. H. Carpenter admitted: «Tolkien made up his mythology in this way, because he wanted it to be unusual and, at the same time, not false. He wanted myths and legends to reflect his own moral ideas about the universe» [1, p. 145]. The latter resonates with the modern definitions of the genre of fantasy as a special model of the world, which laws «in terms of determinism seem absolute lawlessness, an adherent artistic model of the world» [3, p. 109]. At the same time, the fantasy world is a certain artefact characterized by the eternal existence of the Universe, living according to the writer's (c) O. Kozii, 2019 
creation laws that are real for this world, and therefore is perceived as a parallel one» [2, p. 191]. A. Gusarova considers the creation of a demiurge as «linguistic, mythological, geographic and other detailed pictures of the imaginary world. $<\ldots>$ Due to it the first, the alogical world becomes deterministic and logical» [2, p. 192].

Being fond of Welsh and Finnish, Scandinavian and Celtic mythology, Tolkien used the elements of the latter to build a model of his own artistic world. But, according to $\mathrm{H}$. Carpenter, «being a Christian, he could not implement his ideas into the Universe without a god $<\ldots>$. God is present in the work of Tolkien, though remains invisible» [1, p.145]. The artistic world of many works is built around a tree, which is not only a biblical image, but also a part of the social subconscious, archetype. The tree is one of the universal symbols of the spiritual culture of mankind is the central world axis that unites Heaven and Earth, man and his way to spiritual heights, the cycles of life, the universe and its processes of eternal and constant renewal, wisdom and mysterious laws of being.

Tolkien chooses the first source of light for his world as a man-made one: Aulë (one of the valar, the patron of the blacksmith's craft) takes two bright lights at the request of Yavanna (the protector of all living creatures). Therefore, the demiurge turns a tree into a symbol of the solar energy. In the world of Tolkien, it is not only an embodiment of the living energy of nature, but also shrouded by humanistic pathos, as the golden and silver trees - Telplion and Laurelin - grew by the blessing of Yavanna, who «blessed the seeds and for a long time had been sitting on the green grass singing the Song of Behest in which all the thoughts of everything that grew upon the earth were invested» [5, p. 1101]. And Nienna (the female deity, imbued with eternal grief and pity for all living., in fact, was a personalization of humanistic ideals) at this time, apparently, knowing about the sad lot of the trees, at that time being «silent and washed the mound with her tears» [5, p. 1101]. The demiurge-writer describes the appearance of the Two Valinor Trees as «the most beautiful creatures of Yavanna», anticipatingly pointing out that «all the legends of the Ancient Epoch will be associated with them» [5, p. 1101]. 
Multidimensionality of the collective image of the Great Trees of Valinor has a spontaneously evolutionary character. The Scripture, describing the process of creating the world, emphasizes the spatial stratification of the sky and earth, water and land. Tolkien, in the universe of which, as already noted, God is present, is trying to synthesize the energy of light and water: «The light dew of Telperion and the rain of Laure-

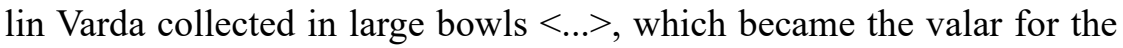
whole earth sources of water and light» [5, p. 1101]. The invisible presence of the creator and the mentioned synthesis of verses determines the pantheistic laws of the existence of the Middle Earth world.

The Melkor, the rebel, was filled with hatred towards trees and with the help of the Ungoliant, the repository of chaos and darkness, who existed within the shape of a giant spider, destroyed the Trees, poisoned dew in the bowls and stole Sylmarils. In the idyll of Valinor the tree becomes a world-centered essence. The killing of the Two Trees is comparable to the Big Bang, the original combination of Thanatos and Eros, as this event becomes the source for the world creation via internal destruction.

The writer determines various aspects of the image of the Great Tree, since «on the top of the hill $<\ldots>$ Varda created for them (the first elves) a tree similar to Telperion $<\ldots>$. It was called Galathion. Then it was planted in the garden $\langle\ldots\rangle$, and was the first to begin with many such trees» [5, p. 1117].

From Celeborne-tree, the writer traces the genealogy of the White Tree of Gondor via the Numenor Nimlot, the organizing center of the given island. Sauron, having reached the island and received some power, poisoning the thoughts of the rulers, prohibits approaching the Tree. That's why Isildur secretly crawls up to it at night and steals the fruit, and then escapes from Numenor. The king follows the order of Sauron and destroys the tree, burning it, the smoke of which is winding for seven, as if giving a signal to Valinor.

The destruction of the tree begins the death of the island. The White Tree of Gondor is a symbol of royal power, the embodiment of its fate. Isildur (the one who cut Sauron's finger with the One Ring) planted the seed in the land of Minas Ithil, in order to fix the affinity with the 
Numenorians with the help of the tree, and via them with the elves and the valar themselves. Having captured this fort, Sauron first burns a tree, confirming by the act of destruction the power of this symbol in accumulating moral and state power. The hope of revival is embodied by the writer in a germ, which gives life to the White Gondor Tree instead. The latter is the reflection, the embodiment of the destiny of the state, since it perishes, in order to be reborn in the seedlings found by the new king: «Aragorn turned and noticed a green spot over a stony slope. He quickly jumped up and saw a young tree $<\ldots>$. The long, tiny leaves on it were dismounted, dark and silver skylights on the top, the tree was crowned with a bundle of flowers with white <...> petals» [5, p. 1029]. Gandalf speaks of the fateful function of a fragile plant: «Such a seed ripens rarely, but the power of life can drown in it for centuries, no one can predict the time of awakening. $<\ldots>$ When the seed ripens, the tree must be planted so that the race is not interrupted» $[5$, p. 1029].

The writer determines the function of the tree as a source of light, giving the ability to revive. After the destruction of the Tree, «Nienna's tears could not heal wounds, but Yavanna for a long time sang in the dark». At that moment, when hope was almost abandoned, Telperion gave a huge silver flower, and Laurelin produced the only golden fruit» [5, p.1147], which then became the sun and the moon. Thus, Tolkien defines the ways of a multi-dimensional development, of evolution, of such a Big Bang in his world, and at the same time allows it some authenticity, truthfulness, correlation with the real, since the professor noted that his Middle Earth is our Earth in ancient times, when the continents were different in shape» [1].

The interpretation of the «living tree» as both friendly and angry with the human race can be found in the first part of «The Lord of the Rings». Having left Hobbiton the four friends could die because of the insidious Old Willow Man as «the trees here (in the Enchanted Forest) are more alive than at home» [5, p. 287].

In Tolkien's mythology tree pastors awake awhile with other immortal elves, because their destiny was inextricably linked with the fate of Arda-Earth, and they were entrusted with the mission of protecting natural riches and experiencing all pain. This affinity is noted by Fangorn, 
meeting with the hobbits: «The ents are somehow like elves: we do not take so much care of ourselves as people, and penetrate deeper into the essence of things. On the other hand, we are similar to people: we change faster than elves, adapt rather than change. Apparently, ents surpass both» $[5$, p. 604].

Ents embody the living soul and the wisdom of nature, are the guardians of goodness. The depth of Fangorn's image of, his semantic load is traced through a portrait. Hobbits at the meeting were mostly struck by his eyes: «Dark brown, near-located, in the bottomless depth of which there sparkled greenish lights» [5, p. 599]. The writer via Hobbit Pippin compares those eyes with the deepest wells in the world, in which there was «the memory of ages and endless wisdom» [5, p. 599]. Ents embody the archetypal synthesis of the world tree and the wise elder one, standing at the head of the genus, at its origins.

The writer himself noted that hobbits, as a collective image, have their own traits: «I'm a hobbit in fact», Professor once admitted, « a hobbit in everything except height. I love trees, gardens, smoke the pipe, prefer easy food» [1, p. 273]. Tolkien embodies his love for languages and trust in the power of a word within Fangorn: «My name is real and long, - he says to his guests. - It grew with me, and I live long, and so it is a whole story. $<\ldots>$ And our language is history» [5, p. 601].

Tolkien is also the author of a number of philosophical tales. These are «Roverandom» - a story of a dog written for Tolkien's son, who was upset by a lost toy; «Smith of Wootton Major» in which the writer touches upon the problem of talent and spiritual potential; the story which is real Professor"s confession - «Leaf by Niggle». The image of the tree is found in the last two works.

The mysterious star of the cake, having fallen into the mouth of the guy («Smith of Wootton Major»), strangely appears on his forhead, to accompany him until the time when he has to find successor of his, because «such things are received only for a certain time» [6, p. 139].

The image of the so-called Royal Tree, which Smith comes across in the Magic Land, is similar to the above-described descriptions of the World Tree from the legends of many cultures: «It seemed as if the 
branches were reaching the heavens, a dazzling light like as a light of the midday sun was coming from it; the leaves were rustling on the tree, flowers were blossoming, and fruit were ripening at the same time» $[6, \mathrm{p}$. 129]. Tolkien does not ignore the exclusiveness of his hero, who has innate observation, and therefore «every leaf, every flower, and every fruit» the Smith accepts «not like others» [6, p. 129].

Once in the morning, Tolkien woke up with a ready-made fairy tale and immediately wrote it. That was the «Leaf by Niggle», in which the writer «expressed his worst fears concerned with his mythological Tree. He felt that he, like his hero, would be torn from work long before it had to be completed» [1, p. 308].

The depth of the perception of the artist («The Leaf by Niggle») the writer transforms into world creation. Niggle works much on details, but dreams of drawing the whole tree. The artist is inspired by a picture of a living tree, the embodiment of the mythological universe. Niggle himself becomes a creator, a demiurge: «At first he saw a leaf taken up by the wind. Then the leaf turned into a tree, it grew, spread forth many branches and penetrated with incredible roots to the earth's interior. A strange bird flew to it and sat down on the branch $<\ldots>$. Then around the Tree and behind it, in the gaps between the leaves and the branches, the outskirts outlined» $[6$, p. 228].

The relationship between the creator and creation is a reflection of the ancient beliefs of a man and a tree as unity, that the tree could become a friend, a «twin brother» of a man, the incarnation of his soul. The tree becomes the creating centre of the main character's own universe, the logical conclusion of the artist's life search. Therefore, when Niggle sees «the tree, his tree, finally finished», he calls it a gift, «referring to art in general and the result in particular» [6, p. 241]. Not only mastery, but the power of the artist's imagination is in the focus of the writer's attention. When Niggle finds himself in front of his Tree, he sees all the leaves in their places, even, «not as he portrayed them, but how he saw them in his $\operatorname{mind} \gg[6$, p. 241].

The writer gradually opens the world of paintings to the readers. Firstly, he determines the place of the Tree in the Woods: «Later, Niggle turns 
to the Forest. Not because the Tree bored him, on the contrary, it seemed to be stamped in his memory» [6, p. 244]. When the mountains, which were not the part of the picture, appear, although they «connected it with something else» [6, p. 245], the artist himself becomes the personification of the creative process. This process does not end with the transition to another world, and the hero is a link that combines two worlds - real and created by himself. The other world is out of time. Therefore, among the trees formed by the imagination, or only by Niggle's subconsciousness, «something was seen far away - it was the next stage, the next picture» [6, p. 245].

The image of the tree has a double semantic sense: firstly, it is the result of the painstaking work of the master, and secondly - the embodiment of the belief in the resettlement of the soul.

So, symbolizing the synthesis of heaven, earth and water, the dynamics of life, combining the worlds, the tree in the creation of Tolkien is a complex archetypal derivative that accumulates feminine as a source of life, male as a defender of the genus. The Trees of Valinor, lone tree-pastors, the creations of Niggle are characterized by the synthesis of cosmogonic and solar aspects.

\section{References}

1. Carpenter, H. 2002. J. R. R. Tolkien. A Biography. Moscow, EKSMO, 432 p.

2. Gusarova, A. 2007. The type of fantasy narration (supernature as the genre criterion) / cited from Gusarova, A. 2006. Russian fantasy on the crossing of the epochs: the matters of The International Scientific Conference. March $21-23$, 2006. Moscow. Moscow University Publishing House.

3. Kovtun, Y. 1998. The true reality of fantasy. The bulletin of Moscow University. Series 9 , philology. Issue 3.

4. Dictionary of Symbols URL: http://www.newacropol.ru/Alexandria/symbols/ tree/

5. Tolkien, J. R. R. 2002. The Total History of Middle Earth. Moscow, AST, 1341 p.

6. Tolkien, J. R. R. 2003. Short stories. Moscow, AST, 252 p.

7. Zavadskaya, V. 2003. The analysis of artistic peculiarities of «The Lord of the Rings» and «Hobbit, or There and Back Again» by Tolkien. Foreign Literature in Ukrainian Secondary Schools. Issue 5. Pp. 52-55. 


\section{Анотація \\ О.Б. Козій. Образ дерева як втілення філософських концептів у твор- чості Дж. Толкісна}

Дерево є одним з універсальних символів духовної культури людства. У створеному Дж. Толкієном світі, дерево є образом містким і неоднозначним; це не пейзажна деталь, а повноцінний образ-символ, що тяжіє до образу-персонажу; воно - динамічний багатоаспектний синтез космогонічного та солярного аспектів.

Будучи залюбленим у валійську та фінську мови, у скандинавську та кельтську міфологію, Дж. Толкієн використовує їх елементи для побудови моделі власного художнього світу. Будучи християнином, він не міг помістити свої уявлення у Всесвіт, де немає бога. Бог присутній у творінні Дж. Толкієна, хоч і лишається незримим. При цьому дерево так чи інакше $\epsilon$ втіленням божественного.

Стародавні вірування в те, що дерево відігравало роль «мосту», посередника між богами й людьми, людиною та її предками Дж. Толкієн втілює через прийом зустрічі художника Ніггла із таємничими Голосами, суддями 3 потойбіччя. Геній отримує шанс продовжувати працювати, або, сам ставши творцем, переміщується із виміру фізичного існування у власний світ. Образ Дерева при цьому має подвійне смислове навантаження: по-перше, це результат кропіткої роботи майстра, а по-друге - втілення віри про переселення душі.

Отож, символізуючи синтез неба, землі й води, динаміку життя, поєднуючи світи, дерево у творінні Дж. Толкієна є складним архетиповим похідним, що акумулює жіноче як джерело життя, чоловіче - захисника роду. Дерева Валінору, самотні деревопастирі, творіння художника Ніггла характеризуються синтезом космогонічного та солярного аспектів.

Ключові слова: дерево, космогонічний і солярний аспекти, персоніфікація, детермінізм, Дж. Толкієн.

\section{Аннотация \\ О.Б. Козий. Образ дерева как воплощение философских концептов в творчестве Дж. Толкина.}

Дерево является одним из универсальных символов духовной культуры человечества. В созданном Дж. Толкином мире, дерево является образом ёмким и неоднозначным; это не только пейзажная деталь, а вполне полноценный образ-символ, тяготеющий к наполненности образа-персонажа; это динамичный многоаспектный синтез космогонического и солярного аспектов. 
Дж. Толкин использует элементы скандинавской и кельтской мифологии для построения модели собственного художественного мира. Будучи христианином, он не мог поместить свои представления во Вселенную, где нет бога. Поэтому Бог присутствует в творении Дж. Толкина, хотя и остаётся незримым. При этом сам мир концентрируется вокруг дерева. Основные исторические эпохи в этом мире так или иначе связаны с деревом.

Древние верования в то, что дерево играло роль «моста», посредника между богами и людьми, человеком и его предками Дж. Толкин воплощает при помощи приёма встречи художника Ниггла с таинственными Голосами, судьями из потустороннего мира. Гений получает шанс продолжать работать. Став творцом, он переходит из мира физического существования в собственный мир. Образ Дерева при этом имеет двойную смысловую нагрузку: во-первых, это результат кропотливой работы мастера, а во-вторых - воплощение веры в переселение души.

Таким образом, символизируя синтез неба, земли и воды, динамику жизни, соединяя миры, дерево в творчестве Дж. Толкина является сложной архетипической производной, аккумулирующей женское начало, как источник жизни, и мужское - как защитника рода. Древа Валинора, одинокие древопастыри, творение художника Ниггла характеризуются синтезом космогонического и солярного аспектов.

Ключевые слова: дерево, космогонический и солярный аспекты, персонификация, детерминизм, Дж. Толкин.

\section{Summary}

\section{O. Kozii. The Image of a Tree as the Embodiment of Philosophical Con- cepts in J. R. R. Tolkien's Oeuvre}

English linguist Tolkien is world-famous as the creator of the fantasy genre and the author of the epic novel «The Lord of the Rings» which has overgrown the measures of a novel having become a cultural phenomena. The tree is one of the universal symbols of the spiritual culture. It unites the Earth with the heaven, defines the human's way to oneself, to spiritual summits. In the works of J. R. R. Tolkien the tree isn't just a detail but also a character, the symbol of the eternal life circulation. Symbolizing the synthesis of heaven, earth and water, the dynamics of life, combining the worlds, the tree in the creation of Tolkien is a complex archetypal derivative that accumulates feminine as a source of life, male as a defender of the genus.

Being fond of Welsh and Finnish, Scandinavian and Celtic mythology, Tolkien used the elements of the latter to build a model of his own artistic world. But being a Christian, he could not implement his ideas into the Universe without a god. God is present in the work of Tolkien, though remains invisible. The artistic 
world of many works is built around a tree, which is not only a biblical image, but also a part of the social subconscious, archetype.

The close relationship between the creator and creation is a reflection of the ancient beliefs about man and the tree as indivisible unity, that the tree could become a friend, a «twin brother» of a man, the incarnation of his soul.

The tree becomes the creating centre of the main character's own universe, the logical conclusion of the artist's life search. Not only mastery, but the power of the author's imagination is in the focus of the writer's attention.

Key words: tree, personification, cosmological and solar aspects, determinism, J.R.R. Tolkien.

\section{Інформація про автора}

Козій Ольга Борисівна - кандидат філологічних наук, доцент кафедри лінгводидактики та іноземних мов Центральноукраїнського держаного педагогічного університету імені Володимира Винниченка; вул. Шевченка, 1, м. Кропивницький, Кіровоградська область, 25000, Україна; е-mail: olykaaaa@gmail.com; https://orcid.org/ 0000-0002-9478-9502 